\title{
Poor oral hygiene and risk of esophageal squamous cell carcinoma in Kashmir
}

\author{
N A Dar ${ }^{\star}, 1,2$, F Islami ${ }^{2,3}$, G A Bhat ${ }^{1}$, I A Shah ${ }^{1}$, M A Makhdoomi ${ }^{1}$, B lqbal ${ }^{1}$, R Rafiq ${ }^{1}$, M M Lone ${ }^{4}$, C C Abnet ${ }^{5}$ \\ and $P$ Boffetta ${ }^{2,6}$ \\ ${ }^{1}$ Department of Biochemistry, University of Kashmir, Hazratbal Srinagar, JK 190006, India; ${ }^{2}$ The Tisch Cancer Institute and Institute \\ for Transitional Epidemiology, Mount Sinai School of Medicine, New York, NY 10029, USA; ${ }^{3}$ Digestive Disease Research Center, \\ Shariati Hospital, Tehran University of Medical Sciences, Tehran 14117, Iran; ${ }^{4}$ Department of Radiation Oncology SK Institute of \\ Medical Sciences, Soura Srinagar 190011, India; ${ }^{5}$ Nutritional Epidemiology Branch, Division of Cancer Epidemiology and Genetics, \\ National Cancer Institute, Rockville, MD 20852, USA and 'International Prevention Research Institute, Lyon 69006, France
}

Background: Several studies have suggested an association between poor oral health and esophageal squamous cell carcinoma (ESCC). We conducted a case-control study in Kashmir, a region with relatively high incidence of ESCC in north India, to investigate the association between oral hygiene and ESCC risk.

Methods: We recruited 703 histologically confirmed ESCC cases, and 1664 controls individually matched to the cases for age, sex, and district of residence. Conditional logistic regression models were used to calculate odds ratios (ORs) and $95 \%$ confidence intervals (Cls).

Results: We found an inverse association between teeth cleaning and ESCC risk. As compared with never cleaning teeth, the OR $(95 \% \mathrm{Cl})$ was $0.41(0.28-0.62)$ for cleaning less than daily and $0.44(0.25-0.77)$ for cleaning at least once a day $(P$ for trend $=0.026)$ in models adjusted for multiple potential confounders, including several indicators of socioeconomic status. This association persisted after we limited our analyses to never tobacco users. The inverse association between cleaning teeth and ESCC was stronger with using brushes than with using sticks/fingers. We also found an association between the number of decayed, filled, and missing teeth and ESCC risk, but the trend of the associations was not statistically significant. Avoiding solid food and cold beverages because of teeth and oral problems were also associated with ESCC risk.

Conclusion: We found an association between poor oral hygiene indicators and ESCC risk, supporting the previous studies that showed the same associations.

Tobacco smoking and heavy alcohol consumption are major risk factors of esophageal squamous cell carcinoma (ESCC) in Western countries (Kamangar et al, 2009). However, in areas with high incidence of ESCC, including central China and northern Iran, these habits are not major risk factors, as many cases of ESCC occur in never smokers and never drinkers (Islami et al, 2004; Tran et al, 2005). Although several risk factors have been suggested, the major factors contributing to ESCC in those high-incidence areas are yet to be established (Kamangar et al, 2009). An association between indicators of poor oral hygiene and ESCC has been reported in several studies from very high-risk areas of China (Abnet et al, 2001, 2005b) and Iran (Sepehr et al, 2005; Abnet et al, 2008b), and from other areas including Latin America, Europe, and Japan (Guha et al, 2007; Hiraki et al, 2008). However, a few studies have not supported this association (Abnet et al, 2005a; Michaud et al, 2008).

ESCC is the most common cancer in Kashmir Valley in India (Khuroo et al, 1992), where similar to other high-incidence areas, little is known about the etiology of ESCC. We aimed to investigate the association between poor oral hygiene and ESCC risk in the overall population and in never tobacco users in Kashmir. 


\section{MATERIALS AND METHODS}

Subject selection. All cancer cases were recruited at the Regional Cancer Centre and Department of Radiation Oncology of Sher-iKashmir Institute of Medical Sciences (SKIMS) from September 2008 to January 2012. Every case in the study was histopatologically confirmed as ESCC and had no previous cancer.

For each case subject, at least one control individually matched to the case for sex and age ( \pm 5 years), and district of residence was recruited from in-patient wards of SKIMS, the Government Medical College Hospital, Srinagar, and 10 district hospitals. Patients were enrolled as controls only when the disease for which they had been admitted did not have a strong association with tobacco or alcohol consumption. The participation rate for cases and control was 96 and 98\%, respectively. Other information about the study design and major reasons for hospitalizations of the enrolled controls are provided in detail elsewhere (Dar et al, 2012). This study was reviewed and approved by the Institutional Ethics Committee of SKIMS.

Data collection. Structured questionnaires were administered in face-to-face interviews at hospitals by trained interviewers who were able to speak in participants' primary language. A limited number of staff conducted the interviews and no proxies were used. Detailed information on demographic characteristics, habits, including lifelong history of use of alcohol and several tobacco products, and intake of fresh fruits and vegetables, was collected. Ever use of alcohol and tobacco products was defined as the use of the respective product at least weekly for a period of 6 months or more. To assess the socioeconomic status (SES), we built a composite score for wealth, based on appliances ownership and other variables by using multiple correspondence analysis (Islami et al, 2009). This score had shown some association with ESCC risk in this population independent of education level (Dar et al, 2013). The detailed information about consumption of the various fruits and vegetables was collected using a semi-quantitative food frequency questionnaire. We asked about the usual frequency of use in a day, week, or month and the amount of use in each instance. Using this information, we calculated the intake of each fruit and vegetable in grams per day. In order to cover the intake of seasonal fruits/vegetables, we also collected data on the number of months in which any of these food items had been consumed: the daily intake in these cases was multiplied by the number of months of consumption and divided by 12 . The daily intake of all fruits and vegetables were summed up to estimate the total fruit/vegetable intake per day.

The study interviewers, who had been trained by dentists to conduct oral cavity examinations, counted each patient's teeth, recorded number of decayed, missing or filled teeth (the sum of which was DMFT score), and obtained information on teeth brushing habits and the type of instrument used to clean the teeth. Many people in Kashmir do not use modern oral care products. The use of teeth cleaning sticks and twigs (such as willow twigs) and rubbing teeth with charcoal and ash (Dandas) with the fingers is still more common than using brushes and prepared dentifrices (Kaur, 2009; D'Cruz and Aradhya, 2012). In addition, information about the type of foods avoided because of tooth or oral problems was collected.

Statistical analysis. In categorizing the continuous variables, we attempted to have equal number of controls in each category of respective variables. Fruit and vegetable intake data (grams per day) were transformed to logarithmic values following addition of 0.1 to original values. Conditional logistic regression was used to calculate unadjusted and adjusted odds ratios (ORs) and corresponding 95\% confidence intervals (CIs). All statistical analysis was done using Stata software, version 11 (Stata Corp.,
College Station, TX, USA). Two-sided $P<0.05$ were considered statistically significant.

\section{RESULTS}

A total of 703 ESCC cases and 1664 matched controls were recruited in this study. Distributions of demographic factors, fruit and vegetable intake, and tobacco and alcohol use by case status are shown in Table 1.

\begin{tabular}{|c|c|c|c|}
\hline \multicolumn{4}{|l|}{$\begin{array}{l}\text { Table 1. Characteristics of } 703 \text { ES } \\
\text { Kashmir Valley, India, 2008-2012 }\end{array}$} \\
\hline \multirow[t]{2}{*}{ Characteristics } & \multirow{2}{*}{$\frac{\text { Cases (\%) }}{61.6(11.1)}$} & \multirow{2}{*}{$\begin{array}{l}\text { Controls (\%) } \\
59.8(11.1)\end{array}$} & P-value \\
\hline & & & $<0.001$ \\
\hline Sex & & & 0.78 \\
\hline Men & $393(55.9)$ & $920(55.3)$ & \\
\hline Women & $310(44.1)$ & $744(44.7)$ & \\
\hline Ethnicity & & & 0.58 \\
\hline Kashmiri & $682(97.0)$ & $1619(97.3)$ & \\
\hline Gojri & $11(1.6)$ & $16(1.0)$ & \\
\hline Pahari & $9(1.3)$ & $27(1.6)$ & \\
\hline Other & $1(0.1)$ & $2(0.1)$ & \\
\hline Place of residence & & & $<0.001$ \\
\hline Urban & $29(4.1)$ & $146(8.8)$ & \\
\hline Rural & $674(95.9)$ & $1518(91.2)$ & \\
\hline Education & & & $<0.001$ \\
\hline No school & $626(89.0)$ & $1074(64.5)$ & \\
\hline Primary (<5th) & $33(4.7)$ & $203(12.2)$ & \\
\hline Middle (5th-8th ) & $24(3.4)$ & $123(7.4)$ & \\
\hline High school (9th-12th) & $16(2.3)$ & $149(8.9)$ & \\
\hline Graduates and higher & $4(0.6)$ & $115(7.0)$ & \\
\hline Wealth score & & & $<0.001$ \\
\hline Quintile 1 (lowest) & $397(56.5)$ & $337(20.2)$ & \\
\hline Quintile 2 & $112(15.9)$ & $328(19.7)$ & \\
\hline Quintile 3 & $66(9.4)$ & $334(20.1)$ & \\
\hline Quintile 4 & $70(10.0)$ & $333(20.0)$ & \\
\hline Quintile 5 & $58(8.2)$ & $332(20.0)$ & \\
\hline $\begin{array}{l}\text { Fresh fruit and vegetable intake, } \\
\text { median g per day (inter-quartile range) }\end{array}$ & $7.9(3.82-12.6)$ & $25.2(12.0-61.0)$ & $<0.001$ \\
\hline Hookah smoking (hookah-years) & & & $<0.001$ \\
\hline Never & $278(39.5)$ & 968 (58.2) & \\
\hline $1-139$ & $98(13.9)$ & $227(13.7)$ & \\
\hline $140-240$ & $113(16.0)$ & $242(14.6)$ & \\
\hline$>240$ & $214(30.4)$ & $225(13.5)$ & \\
\hline Cigarette smoking (pack-years) & & & 0.094 \\
\hline Never & $633(90.0)$ & $1437(86.3)$ & \\
\hline $1-6.2$ & $23(3.2)$ & $78(4.7)$ & \\
\hline $6.3-13.1$ & $21(3.0)$ & $73(4.4)$ & \\
\hline$\geqslant 13.2$ & $26(3.7)$ & $76(4.6)$ & \\
\hline Bidi ever smoking & $15(2.1)$ & $3(0.2)$ & $<0.001$ \\
\hline Nass chewing (nass-years) & & & $<0.001$ \\
\hline Never & $501(71.5)$ & $1471(88.5)$ & \\
\hline $1-119$ & $46(5.6)$ & $53(3.2)$ & \\
\hline $120-199$ & $37(5.2)$ & $70(4.2)$ & \\
\hline$\geqslant 200$ & $117(16.7)$ & $69(4.1)$ & \\
\hline Gutka ever chewing & $10(1.4)$ & $13(0.8)$ & 0.01 \\
\hline Alcohol ever use & $8(1.1)$ & $0(0.0)$ & $<0.001$ \\
\hline $\begin{array}{l}\text { Abbreviation: } E S C C=\text { esophageal squam } \\
\text { a Although cases and controls were indi } \\
\text { controls are not necessarily equal in ea } \\
\text { matched control and others have more } \\
\text { numbers due to missing data in some } \\
\text { categorical variables } \chi^{2} \text { for trend in va } \\
\text { Wilcoxon Rank Sum tests for continuous }\end{array}$ & $\begin{array}{l}\text { cell carcinoma. } \\
\text { ually matched, the } \\
\text { sex category, bec } \\
\text { trols. Numbers } \\
\text { iables. P-values } \\
\text { les with more th } \\
\text { iables. }\end{array}$ & $\begin{array}{l}\text { a percentages of } \\
\text { ause some cases } \\
\text { hay not add up to } \\
\text { alculated using } \chi^{2} \\
\text { an two categories) }\end{array}$ & $\begin{array}{l}\text { cases and } \\
\text { have one } \\
\text { the total } \\
2 \text {-tests for } \\
\text { ) and the }\end{array}$ \\
\hline
\end{tabular}


Approximately 25\% of controls cleaned their teeth at least once a day, whereas 6\% never cleaned their teeth (Table 2). The frequency of teeth cleaning was inversely associated with ESCC risk. As compared with never cleaning teeth, the OR (95\% CI) was $0.41(0.28-0.62)$ for cleaning less than daily and $0.44(0.25-0.77)$ for cleaning at least once a day ( $P$ for trend $=0.026)$. Cleaning teeth with brushes $(\mathrm{OR}=0.11 ; 95 \%$ CI: $0.06-0.20)$ and stick and fingers $(\mathrm{OR}=0.51 ; 95 \% \mathrm{CI}: 0.34-0.77)$ both were associated with lower ESCC risk. On the other hand, avoiding hard solid foods and cold beverages because of teeth and oral cavity problems were associated with higher ESCC risk. The loss of adult teeth was associated with ESCC risk in unadjusted models, but not in adjusted models. Compared with the referent groups, some categories of the number of decayed, missing, and filled teeth and of DMFT criteria were associated with ESCC risk. However, there was no monotonic trend for the association across increasing categories of exposure.

In never users of any type of tobacco (never smokers and never chewers), the magnitude of the associations between tooth

Table 2. ORs (95\% Cls) for the association of high ESCC risk with oral health variables in Kashmiri population

\begin{tabular}{|c|c|c|c|c|c|}
\hline Variables & Cases (\%) & Controls (\%) & $\begin{array}{l}\text { Unadjusted OR } \\
(95 \% \mathrm{Cl})\end{array}$ & $\begin{array}{l}\text { Adjusted OR } 1 \\
(95 \% \mathrm{Cl})^{\mathrm{a}}\end{array}$ & $\begin{array}{l}\text { Adjusted OR } 2 \\
(95 \% \mathrm{Cl})^{\mathrm{b}}\end{array}$ \\
\hline \multicolumn{6}{|l|}{ Frequency of cleaning teeth } \\
\hline $\begin{array}{l}\text { Never } \\
\text { Less than daily } \\
\text { Daily at least once } \\
P \text { for trend }\end{array}$ & $\begin{array}{r}161(23.0) \\
460(65.5) \\
81(11.5)\end{array}$ & $\begin{array}{c}101(6.2) \\
1130(69.1) \\
405(24.7)\end{array}$ & $\begin{array}{c}\text { Referent } \\
0.25(0.19-0.34) \\
0.11(0.07-0.16) \\
<0.001\end{array}$ & $\begin{array}{c}\text { Referent } \\
0.41(0.28-0.62) \\
0.44(0.25-0.77) \\
0.026\end{array}$ & $\begin{array}{l}- \\
- \\
- \\
-\end{array}$ \\
\hline \multicolumn{6}{|l|}{ Instrument used to cleaning teeth } \\
\hline $\begin{array}{l}\text { Do not clean teeth } \\
\text { Brush } \\
\text { Stick or finger }\end{array}$ & $\begin{array}{c}161(23.0) \\
50(7.2) \\
488(69.8)\end{array}$ & $\begin{array}{l}101(6.2) \\
528(33.3) \\
957(60.3)\end{array}$ & $\begin{array}{c}\text { Referent } \\
0.05(0.03-0.07) \\
0.31(0.23-0.42)\end{array}$ & $\begin{array}{c}\text { Referent } \\
0.11(0.06-0.20) \\
0.51(0.34-0.77)\end{array}$ & $\begin{array}{l}- \\
- \\
-\end{array}$ \\
\hline \multicolumn{6}{|c|}{ Avoiding food because of tooth problem } \\
\hline $\begin{array}{l}\text { No problem and no food avoided } \\
\text { Hard solid foods or cold beverages }\end{array}$ & $\begin{array}{l}523(78.9) \\
140(21.1)\end{array}$ & $\begin{array}{r}1426(89.1) \\
175(10.9)\end{array}$ & $\begin{array}{c}\text { Referent } \\
2.06(1.59-2.66)\end{array}$ & $\begin{array}{c}\text { Referent } \\
2.38(1.64-3.45)\end{array}$ & - \\
\hline \multicolumn{6}{|l|}{ Adult tooth loss } \\
\hline $\begin{array}{l}\text { No } \\
\text { Yes }\end{array}$ & $\begin{array}{l}108(15.3) \\
595(84.7)\end{array}$ & $\begin{array}{r}417(25.0) \\
1247(75.0)\end{array}$ & $\begin{array}{c}\text { Referent } \\
1.96(1.52-2.51)\end{array}$ & $\begin{array}{c}\text { Referent } \\
1.31(0.92-1.87)\end{array}$ & - \\
\hline Number of decayed teeth, median (IQR) & $3(2-4)$ & $2(1-4)$ & & & \\
\hline $\begin{array}{l}\text { Category } 1(0-1) \\
\text { Category } 2(2) \\
\text { Category } 3(3-4) \\
\text { Category } 4(\geqslant 5) \\
P \text { for trend }\end{array}$ & $\begin{array}{l}107(15.2) \\
204(29.1) \\
271(38.7) \\
119(17.0)\end{array}$ & $\begin{array}{l}419(28.8) \\
427(29.4) \\
338(23.2) \\
271(18.6)\end{array}$ & $\begin{array}{c}\text { Referent } \\
1.98(1.49-2.63) \\
3.26(2.46-4.33) \\
1.90(1.37-2.62) \\
<0.001\end{array}$ & $\begin{array}{c}\text { Referent } \\
2.73(1.83-4.06) \\
3.30(2.21-4.90) \\
1.47(0.93-2.32) \\
0.013\end{array}$ & $\begin{array}{c}\text { Referent } \\
2.64(1.79-4.06) \\
3.11(2.07-4.68) \\
1.52(0.95-2.62) \\
0.014\end{array}$ \\
\hline Number of missing teeth, median (IQR) & $3(1-6)$ & $2(0-5)$ & & & \\
\hline $\begin{array}{l}\text { Category } 1(0) \\
\text { Category } 2(1-2) \\
\text { Category } 3(3-5) \\
\text { Category } 4(\geqslant 6) \\
P \text { for trend }\end{array}$ & $\begin{array}{l}116(16.5) \\
211(30.1) \\
194(27.7) \\
180(25.7)\end{array}$ & $\begin{array}{l}417(28.7) \\
368(25.3) \\
344(23.6) \\
326(22.4)\end{array}$ & $\begin{array}{c}\text { Referent } \\
1.96(1.48-2.60) \\
2.13(1.60-2.84) \\
1.96(1.45-2.66) \\
<0.001\end{array}$ & $\begin{array}{c}\text { Referent } \\
1.39(0.92-2.09) \\
1.51(1.00-2.30) \\
0.91(0.59-1.39) \\
0.523\end{array}$ & $\begin{array}{c}\text { Referent } \\
1.29(0.84-1.98) \\
1.36(0.88-2.11) \\
1.08(0.68-1.69) \\
0.833\end{array}$ \\
\hline Number of filled teeth, median (IQR) & $0(0-0)$ & $0(0-0)$ & & & \\
\hline $\begin{array}{l}\text { Category } 1(0) \\
\text { Category } 2(1) \\
\text { Category } 3(\geqslant 2) \\
P \text { for trend }\end{array}$ & $\begin{array}{c}634(90.6) \\
17(2.4) \\
49(7.0)\end{array}$ & $\begin{array}{c}1313(90.2) \\
86(5.9) \\
56(3.9)\end{array}$ & $\begin{array}{c}\text { Referent } \\
0.46(0.26-0.80) \\
1.64(1.10-2.47) \\
0.256\end{array}$ & $\begin{array}{c}\text { Referent } \\
0.51(0.25-1.01) \\
2.08(1.11-3.89) \\
0.198\end{array}$ & $\begin{array}{c}\text { Referent } \\
0.48(0.29-1.01) \\
1.96(1.00-3.85) \\
0.336\end{array}$ \\
\hline $\mathrm{DMFT}^{\mathrm{c}}$ criteria, median (IQR) & $6(4-10)$ & $5(3-9)$ & & & \\
\hline $\begin{array}{l}\text { Category } 1(0-2) \\
\text { Category } 2(3-4) \\
\text { Category } 3(5-6) \\
\text { Category } 4(7-10) \\
\text { Category } 5(\geqslant 11) \\
P \text { for trend }\end{array}$ & $\begin{array}{r}75(10.9) \\
136(19.7) \\
159(23.1) \\
157(22.8) \\
162(23.5)\end{array}$ & $\begin{array}{l}338(23.7) \\
281(19.7) \\
271(19.0) \\
276(19.3) \\
261(18.3)\end{array}$ & $\begin{array}{c}\text { Referent } \\
2.34(1.66-3.31) \\
2.62(1.86-3.69) \\
2.92(2.07-4.12) \\
3.07(2.15-4.37) \\
<0.001\end{array}$ & $\begin{array}{c}\text { Referent } \\
2.44(1.47-4.03) \\
1.85(1.14-3.00) \\
1.93(1.19-3.13) \\
1.54(0.93-2.54) \\
0.449\end{array}$ & $\begin{array}{l}- \\
- \\
- \\
-\end{array}$ \\
\hline \multicolumn{6}{|c|}{ 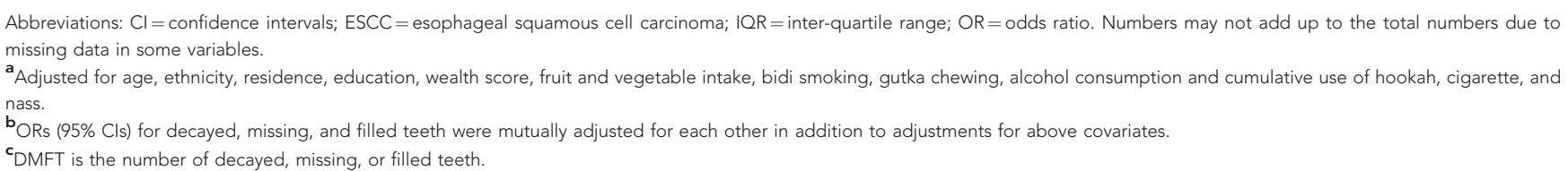 } \\
\hline
\end{tabular}


variables other than the number of decayed teeth and of the inverse association between teeth cleaning frequency and ESCC risk were slightly strengthened (Table 3). The above associations were slightly stronger in never tobacco smokers (Supplementary Table 1) than in never tobacco chewers (Supplementary Table 2).

In analyses stratified by the wealth score, the inverse association between frequency of cleaning teeth and ESCC risk and the association between DMFT criteria and ESCC risk was stronger in people with higher wealth score than those with lower score
(Supplementary Table 3). The other associations in the subgroups were similar to the overall associations.

\section{DISCUSSION}

Our study showed an inverse association between teeth cleaning and ESCC risk in the Kashmir Valley in the overall study and in

Table 3. ORs ( $95 \% \mathrm{Cls}$ ) for the association between oral health indicators and ESCC risk in never tobacco smokers (hookah, cigarette, and bidi) and chewers (nass and gutka)

\begin{tabular}{|c|c|c|c|c|}
\hline Variables & Cases (\%) & Controls (\%) & Unadjusted OR $(95 \% \mathrm{Cl})$ & Adjusted OR $(95 \% \mathrm{Cl})^{a}$ \\
\hline \multicolumn{5}{|l|}{ Frequency of cleaning teeth } \\
\hline $\begin{array}{l}\text { Never } \\
\text { Less than daily } \\
\text { Daily at least once } \\
P \text { for trend }\end{array}$ & $\begin{array}{r}52(27.4) \\
106(55.8) \\
32(16.8)\end{array}$ & $\begin{array}{c}32(4.3) \\
457(61.4) \\
255(34.3)\end{array}$ & $\begin{array}{c}\text { Referent } \\
0.19(0.09-0.40) \\
0.09(0.04-0.22) \\
<0.001\end{array}$ & $\begin{array}{c}\text { Referent } \\
0.25(0.09-0.71) \\
0.34(0.09-1.21) \\
0.392\end{array}$ \\
\hline \multicolumn{5}{|c|}{ Instrument used to cleaning teeth } \\
\hline $\begin{array}{l}\text { Do not clean teeth } \\
\text { Brush } \\
\text { Stick or finger }\end{array}$ & $\begin{array}{r}52(27.4) \\
20(10.5) \\
118(62.1)\end{array}$ & $\begin{array}{c}32(4.5) \\
296(41.2) \\
390(54.3)\end{array}$ & $\begin{array}{c}\text { Referent } \\
0.05(0.02-0.13) \\
0.26(0.12-0.56)\end{array}$ & $\begin{array}{c}\text { Referent } \\
0.10(0.03-0.39) \\
0.34(0.12-0.96)\end{array}$ \\
\hline \multicolumn{5}{|c|}{ Avoiding food because of tooth problem } \\
\hline $\begin{array}{l}\text { No problem and no food avoided } \\
\text { Hard solid or cold beverages }\end{array}$ & $\begin{array}{r}145(81.0) \\
34(19.0)\end{array}$ & $\begin{array}{c}666(90.1) \\
73(9.9)\end{array}$ & $\begin{array}{c}\text { Referent } \\
2.67(1.42-5.03)\end{array}$ & $\begin{array}{c}\text { Referent } \\
4.32(1.54-12.09)\end{array}$ \\
\hline \multicolumn{5}{|l|}{ Adult tooth loss } \\
\hline $\begin{array}{l}\text { No } \\
\text { Yes }\end{array}$ & $\begin{array}{r}31(16.2) \\
160(83.8)\end{array}$ & $\begin{array}{r}243(31.8) \\
522(68.2)\end{array}$ & $\begin{array}{c}\text { Referent } \\
3.14(1.81-5.44)\end{array}$ & $\begin{array}{c}\text { Referent } \\
2.29(1.06-4.95)\end{array}$ \\
\hline \multicolumn{5}{|l|}{ Number of decayed teeth } \\
\hline $\begin{array}{l}\text { Category } 1(0-1) \\
\text { Category } 2(2) \\
\text { Category } 3(3-4) \\
\text { Category } 4(\geqslant 5) \\
P \text { for trend }\end{array}$ & $\begin{array}{l}38(20.1) \\
61(32.3) \\
60(31.7) \\
30(15.9)\end{array}$ & $\begin{array}{l}203(30.4) \\
212(31.8) \\
151(22.6) \\
101(15.2)\end{array}$ & $\begin{array}{c}\text { Referent } \\
1.51(0.85-2.67) \\
1.89(1.05-3.39) \\
1.04(0.53-2.04) \\
0.500\end{array}$ & $\begin{array}{c}\text { Referent } \\
2.10(0.86-5.14) \\
2.91(1.18-7.16) \\
0.65(0.23-1.83) \\
0.970\end{array}$ \\
\hline \multicolumn{5}{|l|}{ Number of missing teeth } \\
\hline $\begin{array}{l}\text { Category } 1(0) \\
\text { Category } 2(1-2) \\
\text { Category } 3(3-5) \\
\text { Category } 4(\geqslant 6) \\
P \text { for trend }\end{array}$ & $\begin{array}{l}33(17.5) \\
54(28.5) \\
57(30.2) \\
45(23.8)\end{array}$ & $\begin{array}{l}242(36.4) \\
170(25.5) \\
137(20.5) \\
117(17.6)\end{array}$ & $\begin{array}{c}\text { Referent } \\
3.11(1.64-5.90) \\
3.88(2.00-7.51) \\
3.37(1.61-7.02) \\
<0.001\end{array}$ & $\begin{array}{c}\text { Referent } \\
2.75(1.09-6.90) \\
2.23(0.84-5.97) \\
2.10(0.76-5.81) \\
0.171\end{array}$ \\
\hline \multicolumn{5}{|l|}{ Number of filled teeth } \\
\hline $\begin{array}{l}\text { Category } 1(0) \\
\text { Category } 2(1) \\
\text { Category } 3(\geqslant 2) \\
P \text { for trend }\end{array}$ & $\begin{array}{c}173(92.0) \\
3(1.6) \\
12(6.4)\end{array}$ & $\begin{array}{c}608(91.2) \\
35(5.2) \\
24(3.6)\end{array}$ & $\begin{array}{c}\text { Referent } \\
0.35(0.09-1.25) \\
1.86(0.69-4.94) \\
0.654\end{array}$ & $\begin{array}{c}\text { Referent } \\
0.29(0.05-1.78) \\
2.64(0.49-14.34) \\
0.693\end{array}$ \\
\hline \multicolumn{5}{|l|}{$\mathrm{DMFT}^{\mathrm{b}}$ criteria } \\
\hline $\begin{array}{l}\text { Category } 1(0-2) \\
\text { Category } 2(3-4) \\
\text { Category } 3(5-6) \\
\text { Category } 4(7-10) \\
\text { Category } 5(\geqslant 11) \\
P \text { for trend }\end{array}$ & $\begin{array}{r}26(13.9) \\
32(17.1) \\
48(25.7) \\
40(21.4) \\
41(21.9)\end{array}$ & $\begin{array}{r}188(28.7) \\
154(23.5) \\
110(16.8) \\
112(17.1) \\
91(13.9)\end{array}$ & $\begin{array}{c}\quad \text { Referent } \\
2.34(1.07-5.15) \\
4.90(2.17-11.04) \\
3.13(1.49-6.61) \\
4.12(1.78-9.56) \\
\quad<0.001\end{array}$ & $\begin{array}{c}\text { Referent } \\
3.16(1.02-9.82) \\
2.92(0.89-9.60) \\
2.64(0.94-7.41) \\
2.15(0.65-6.84) \\
0.244\end{array}$ \\
\hline
\end{tabular}


never tobacco users. We also found associations between risk of ESCC and several other indicators of poor oral hygiene.

Our results are in agreement with several other studies (Abnet et al, 2001; Sepehr et al, 2005; Wei et al, 2005; Abnet et al, 2008a, b). Poor oral hygiene can lead to periodontal disease. Periodontal disease and caries both are characterized by chronic bacterial infections, the major causes of tooth damage and loss in adults (Thomas et al, 1994; Papapanou, 1996; Shigli et al, 2009). Tobacco smoking, a risk factor for ESCC, can also cause periodontal disease and tooth loss (Pihlstrom et al, 2005). In addition, low SES, which may be associated with poor oral health, has consistently been linked to ESCC risk (Islami et al, 2009). Therefore, the association between poor oral hygiene and ESCC can be confounded by tobacco use and SES. However, the association between oral hygiene indicators persisted in our study after excluding tobacco users from the analysis. The majority of these associations also persisted in analyses stratified by a composite score for wealth, suggesting that confounding by SES does not explain these findings.

Mechanistic pathways linking oral hygiene and ESCC are currently unknown. Individuals with missing teeth may have a different burden of oral flora and may have communities that more effectively reduce nitrate to nitrite (Eisenbrand et al, 1980), a necessary step in the in-vivo formation of nitrosamines (Nair et al, 1996). This endogenous formation accounts for $45-75 \%$ of a typical individual's nitrosamine exposure (Tricker, 1997). Studies have also shown that oral bacteria that cause periodontal diseases can convert ethanol or dietary sugars into acetaldehyde, a carcinogenic metabolite of ethanol (Salaspuro, 2003a, b). In addition, a periodontal infection can lead to a release of inflammatory mediators (proinflammatory cytokines) (Scannapieco, 2004). The host response to bacterial inflammation are known to have a role in development of cancer (Karin et al, 2006). However, although a meta-analysis of one prospective and six case-control studies have suggested an inverse association between the use of nonsteroidal anti-inflammatory drugs and esophageal cancer (Sun and Yu, 2011), the role of chronic inflammation in ESCC is less clear.

Histological ascertainment of ESCC diagnosis, collection of extensive information on potential confounders, and large sample size were among the strengths of this study. One of the main limitations was that oral examinations were done by interviewers who were not dental care professionals. However, it is unlikely to have major influence on the reported number of missing and filled teeth or in the accurate reporting of oral hygiene practices. Because of retrospective assessments of exposure, information bias might have been existed in assessment of some variables of interest and covariates. However, information bias with teeth counting is unlikely. Finally, although we adjusted our results for multiple potential confounding factors, existence of some unknown confounders in this population or residual confounding could not totally be excluded. Nevertheless, consistency of our main finding in our several sub-analyses and with studies in other population suggests that the association is real.

In summary, this study showed associations between several indicators of poor oral hygiene and ESCC risk, which support the results of the previous studies in several other populations.

\section{ACKNOWLEDGEMENTS}

This study was supported by Extramural grant of Indian Council of Medical Research (ICMR), New Delhi, under IRIS ID 5/13/37/ 2007/-NCD-III. NAD was supported by a fellowship (American Cancer Society international fellowships for beginning investigators (ACSBI)) from the Union for International Cancer Control (UICC).

\section{CONFLICT OF INTEREST}

The authors declare no conflict of interest.

\section{REFERENCES}

Abnet CC, Kamangar F, Dawsey SM, Stolzenberg-Solomon RZ, Albanes D, Pietinen P, Virtamo J, Taylor PR (2005a) Tooth loss is associated with increased risk of gastric non-cardia adenocarcinoma in a cohort of Finnish smokers. Scand J Gastroenterol 40(6): 681-687.

Abnet CC, Kamangar F, Islami F, Nasrollahzadeh D, Brennan P, Aghcheli K, Merat S, Pourshams A, Marjani HA, Ebadati A (2008a) Tooth loss and lack of regular oral hygiene are associated with higher risk of esophageal squamous cell carcinoma. Cancer Epidemiol Biomarkers Prev 17(11): 3062-3068.

Abnet CC, Kamangar F, Islami F, Nasrollahzadeh D, Brennan P, Aghcheli K, Merat S, Pourshams A, Marjani HA, Ebadati A, Sotoudeh M, Boffetta P, Malekzadeh R, Dawsey SM (2008b) Tooth loss and lack of regular oral hygiene are associated with higher risk of esophageal squamous cell carcinoma. Cancer Epidemiol, Biomarkers Prev 17(11): 3062-3068.

Abnet CC, Qiao YL, Dawsey SM, Dong ZW, Taylor PR, Mark SD (2005b) Tooth loss is associated with increased risk of total death and death from upper gastrointestinal cancer, heart disease, and stroke in a Chinese population-based cohort. Int J Epidemiol 34(2): 467-474.

Abnet CC, Qiao YL, Mark SD, Dong ZW, Taylor PR, Dawsey SM (2001) Prospective study of tooth loss and incident esophageal and gastric cancers in China. Cancer Causes Control 12(9): 847-854.

D'Cruz A, Aradhya S (2012) Impact of oral health education on oral hygiene knowledge, practices, plaque control and gingival health of 13-to 15-year-old school children in Bangalore city. Int J Dent Hyg 11(2): 126-133.

Dar NA, Bhat GA, Shah IA, Iqbal B, Kakhdoomi MA, Nisar I, Rafiq R, Iqbal ST, Bhat AB, Nabi S, Shah SA, Shafi R, Masood A, Lone MM, Zargar SA, Najar MS, Islami F, Boffetta P (2012) Hookah smoking, nass chewing, and oesophageal squamous cell carcinoma in Kashmir, India. Br J Cancer 107(9): 1618-1623.

Dar NA, Shah IA, Bhat GA, Makhdoomi MA, Iqbal B, Rafiq R, Nisar I, Bhat AB, Nabi S, Masood A, Shah SA, Lone MM, Zargar SA, Islami F, Boffetta P (2013) Socio-economic status and esophageal squamous cell carcinoma risk in Kashmir, India. Cancer Sci; e-pub ahead of print 31 May 2013; doi:10.1111/cas.12210.

Eisenbrand G, Spiegelhalder B, Preussmann R (1980) Nitrate and nitrite in saliva. Oncology 37(4): 227-231.

Guha N, Boffetta P, Wunsch Filho V, Eluf Neto J, Shangina O, Zaridze D, Curado MP, Koifman S, Matos E, Menezes A, Szeszenia-Dabrowska N, Fernandez L, Mates D, Daudt AW, Lissowska J, Dikshit R, Brennan P (2007) Oral health and risk of squamous cell carcinoma of the head and neck and esophagus: results of two multicentric case-control studies. Am J Epidemiol 166(10): 1159-1173.

Hiraki A, Matsuo K, Suzuki T, Kawase T, Tajima K (2008) Teeth loss and risk of cancer at 14 common sites in Japanese. Cancer Epidemiol Biomarkers Prev 17(5): 1222-1227.

Islami F, Kamangar F, Aghcheli K, Fahimi S, Semnani S, Taghavi N, Marjani HA, Merat S, Nasseri-Moghaddam S, Pourshams A, Nouraie M, Khatibian M, Abedi B, Brazandeh MH, Ghaziani R, Sotoudeh M, Dawsey SM, Abnet CC, Taylor PR, Malekzadeh R (2004) Epidemiologic features of upper gastrointestinal tract cancers in Northeastern Iran. Br J Cancer 90(7): 1402-1406.

Islami F, Kamangar F, Nasrollahzadeh D, Aghcheli K, Sotoudeh M, Abedi-Ardekani B, Merat S, Nasseri-Moghaddam S, Semnani S, Sepehr A, Wakefield J, Moller H, Abnet CC, Dawsey SM, Boffetta P, Malekzadeh R (2009) Socio-economic status and oesophageal cancer: results from a population-based case-control study in a high-risk area. Int J Epidemiol 38(4): 978-988.

Kamangar F, Chow WH, Abnet C, Dawsey S (2009) Environmental causes of esophageal cancer. Gastroenterol Clin North Am 38(1): 27.

Karin M, Lawrence T, Nizet V (2006) Innate immunity gone awry: linking microbial infections to chronic inflammation and cancer. Cell 124(4): $823-835$.

Kaur J (2009) Dental education and oral health problems in India. Indian J Dent Educ 2(4): 167. 
Khuroo MS, Zargar SA, Mahajan R, Banday MA (1992) High incidence of oesophageal and gastric cancer in Kashmir in a population with special personal and dietary habits. Gut 33(1): 11-15.

Michaud DS, Liu Y, Meyer M, Giovannucci E, Joshipura K (2008) Periodontal disease, tooth loss, and cancer risk in male health professionals: a prospective cohort study. Lancet Oncol 9(6): 550-558.

Nair J, Ohshima H, Nair UJ, Bartsch H (1996) Endogenous formation of nitrosamines and oxidative DNA-damaging agents in tobacco users. Crit Rev Toxicol 26(2): 149-161.

Papapanou PN (1996) Periodontal diseases: epidemiology. Ann Periodontol 1(1): 1-36.

Pihlstrom BL, Michalowicz BS, Johnson NW (2005) Periodontal diseases. Lancet 366(9499): 1809-1820.

Salaspuro MP (2003a) Acetaldehyde, microbes, and cancer of the digestive tract. Crit Rev Clin Lab Sci 40(2): 183-208.

Salaspuro MP (2003b) Alcohol consumption and cancer of the gastrointestinal tract. Best Pract Res Clin Gastroenterol 17(4): 679-694.

Scannapieco FA (2004) Periodontal inflammation: from gingivitis to systemic disease? Compend Contin Educ Dent 25(7 Suppl 1): 16-25.

Sepehr A, Kamangar F, Fahimi S, Saidi F, Abnet CC, Dawsey SM (2005) Poor oral health as a risk factor for esophageal squamous dysplasia in northeastern Iran. Anticancer Res 25(1B): 543-546.

Shigli K, Hebbal M, Angadi GS (2009) Relative contribution of caries and periodontal disease in adult tooth loss among patients reporting to the Institute of Dental Sciences, Belgaum, India. Gerodontology 26(3): 214-218.

Sun L, Yu S (2011) Meta-analysis: non-steroidal anti-inflammatory drug use and the risk of esophageal squamous cell carcinoma. Dis Esophagus 24(8): 544-549.

Thomas S, Raja RV, Kutty R, Strayer MS (1994) Pattern of caries experience among an elderly population in south India. Int Dent J 44(6): 617-622.

Tran GD, Sun XD, Abnet CC, Fan JH, Dawsey SM, Dong ZW, Mark SD, Qiao YL, Taylor PR (2005) Prospective study of risk factors for esophageal and gastric cancers in the Linxian general population trial cohort in China. Int J Cancer 113(3): 456-463.

Tricker AR (1997) N-nitroso compounds and man: sources of exposure, endogenous formation and occurrence in body fluids. Eur J Cancer Prev 6(3): 226-268.

Wei W, Abnet C, Lu N, Roth M, Wang G, Dye B, Dong Z, Taylor P, Albert P, Qiao Y (2005) Risk factors for oesophageal squamous dysplasia in adult inhabitants of a high risk region of China. Gut 54(6): 759-763.

This work is published under the standard license to publish agreement. After 12 months the work will become freely available and the license terms will switch to a Creative Commons AttributionNonCommercial-Share Alike 3.0 Unported License.

Supplementary Information accompanies this paper on British Journal of Cancer website (http://www.nature.com/bjc) 